\title{
Commentary: scale, rent, and symbolic capital: political economy and emerging rural landscapes
}

\author{
Nathan F. Sayre
}

Published online: 15 July 2009

(C) The Author(s) 2009. This article is published with open access at Springerlink.com

The papers collected here demonstrate that rural landscapes around the world are increasingly entering into global-scale circuits of capital accumulation and circulation for purposes other than the conventional ones of raw materials, cheap labor and agricultural commodities. Although the concepts of "exurbia" and "amenity migration" remain to be further specified, it is clear that emerging rural landscapes are an important and vast field for empirical and theoretical research. Four common threads run through the diverse cases presented here: (1) fictitious commodification of nature by capital, in various and novel forms that interact with each other and with antecedent forms; (2) the importance of the category of rent (both actual and potential) to understand these processes adequately; (3) the increasing scale, rate, and magnitude of capital production and circulation as drivers that widen the "rent gap" in rural areas; and (4) the symbolic character of capital invested in amenity forms of uneven development. What frequently results are cultural, political, economic and environmental struggles between "locals" and the bearers of extra-local capital, mediated in complex ways by the tension between simple speculation and more persistent varieties of migration. These struggles are the central research challenge that these papers reveal.

\section{N. F. Sayre $(\square)$}

Department of Geography, University of California, 507 McCone Hall \#4740, Berkeley, CA 94720-4740, USA e-mail: nsayre@berkeley.edu
Rural landscapes around the world have been subject to international capital flows for hundreds of years. What is new in recent decades, as demonstrated by the papers collected here, are the goals of these investments: no longer limited to raw materials, cheap labor and agricultural commodities, global capital now seeks out rural sites for tourism, residential development, luxury homes, environmental conservation, and speculation in all of these. These phenomena pose serious challenges not only to the residents and landscapes of rural areas, but also to conventional notions of development, capital, and "the rural" as a category.

It should be emphasized at the outset that these processes both presuppose and reinforce global patterns of inequality and uneven development. The cases examined in this collection reveal widespread and novel phenomena-this is what makes them important and exciting. The larger picture remains stubbornly continuous, however, with the patterns and processes of uneven development witnessed since the emergence of capitalism. The widening disparity of wealth both within and among countries over the past 35 years must be recognized as a fundamental condition of possibility for the advent of most, if not all, of the new rural landscapes analyzed in these papers. Perhaps this goes without saying, but it should not be forgotten.

The concepts of exurbia and amenity migration remain rather underspecified at this point, but the papers assembled here provide an opportunity to 
make significant progress both empirically and theoretically. They show us that today's rural amenities often include things we equate with conservation in a broad sense: wildlife, views, heritage, open space, and biodiversity, for example. But there are others, as well: tourist attractions (of various kinds), residential development, speculative real estate investment, or symbolic capital accumulation on the part of states or NGOs. More than one amenity may occur simultaneously, differentiated not only by the object of investment interest but also by the scale at which each realizes its value-or generates its opposition, as in the case of local activism against breakneck development in New Zealand.

Similarly with exurbia and migration. Some amenity migrants are migrating permanently, some seasonally, some weekly, some daily. Some are recent phenomena, while others have antecedents going back half a century or more. In some cases it isn't people moving so much as it is capital, spreading into rural areas via property values and speculative appreciation well ahead of actual subdivision and building. That many exurbs are dominated by second (or third, etc.) homes suggests a rather peculiar meaning of migration. Exurbia, meanwhile, is clearly defined in relation to urban, suburban, rural and "wild" lands_-but again, at what scale? It is the "wildness" of the Queenstown Lakes District that draws its exurbanites, for instance, but some of them are migrating from Hollywood to build mansions, while many more are migrating from Asia and Europe for vacations.

So what common themes or lessons can be drawn from all these diverse cases? I would identify four. (1) They all involve the (fictitious) commodification of nature by capital, in various and novel forms that interact with each other and with antecedent forms.

(2) The category that best captures these processes is rent, both actual and potential. (3) The increasing scale, rate, and magnitude of capital production and circulation tend to widen the rent gap-the spread between actual and potential rents-in rural areas, both by subjecting agricultural producers to declining prices via global competition and by facilitating access for investments and people from around the world. (4) Finally, what appears to distinguish amenity forms of uneven development is the prominent role of capitals whose form of value is environmental, aesthetic, or leisure-oriented-that is to say, symbolic.
This is not to say that the centrality of production to capital accumulation and social relations is diminished or dislodged, but rather that what is produced now includes ideas, identities, and experiences as well as commodities and surpluses. That amenity-seeking capitals are symbolic in no way diminishes their objective consequences either economically or ecologically. The Nature Conservancy is capable of mobilizing tens of millions of real dollars to protect a forest from logging, demonstrating that "conservation capital" is a genuine force in real estate markets. The source of that capital, however, is donors whose evaluation of worthy causes is unquestionably colored by symbolism. This is true as well of the state, which must strike some balance between economic growth, local legitimacy, and conformance to regional, national and international expectations of governance and investor confidence. The case of Local Landscape Designations in Scotland is fascinating on this point: they "work" symbolically despite being almost pathetically toothless in practice, simply because they send a signal to potential investors and developers that they may expect a battle with local residents if they attempt to alter the landscape in certain ways (Scott 2006, 2009). Protecting rural landscapes, it appears, is often a defensive struggle to prevent the penetration of outside capital.

This highlights the importance of history and politics. The papers collected here make plain that emerging rural landscapes are always historically embedded, both ecologically and socially. The historical has a certain alignment with the political, moreover, since the latter so often turns on claims made by "locals" against "outsiders" who are viewed as "newcomers" who are invading and/or trying to dictate matters from afar. If we take it as a given that the outsiders bring capital with them (otherwise they wouldn't get there, or they wouldn't pose a threat via land use change), there are several ways to think about that capital. Is it merely speculative-surplus from other sites and activities looking for somewhere to be reproduced? To the extent that this is so, amenity landscapes appear as a kind of escape valve for global capital. But what if it is more than merely speculative-if its bearers genuinely seek to become locals and to persist there for the long term, even if only as intermittent residents? The two are not mutually exclusive, and the manner in which these two faces 
of capital struggle with each other is perhaps the central research question these papers reveal, with consequences that are equal parts social, ecological, economic and geographical.

Open Access This article is distributed under the terms of the Creative Commons Attribution Noncommercial License which permits any noncommercial use, distribution, and reproduction in any medium, provided the original author(s) and source are credited.

\section{References}

Scott, A. (2006). Planning for amenity and conservation: Can local landscape designations deliver? Amenity Migration, Exurbia, and Emerging Rural Landscapes 3: Rethinking hegemonic/dominant responses. Chicago: Annual Meeting of the Association of American Geographers, March 8.

Scott, A. (2009). What kind of countryside do we want? Community perspectives from Wales, UK. GeoJournal (this issue). doi:10.1007/s10708-009-9256-y. 